\title{
Probable vertical transmission of SARS Covid-19 infection: A case report
}

\author{
*I M Kumarasiri ${ }^{1}$, S T Yapa ${ }^{1}$, W M C L Weerasinghe ${ }^{1}$, W A K Wanasinghe ${ }^{1}$, Medha Weerasekera ${ }^{2}$
}

Sri Lanka Journal of Child Health, 2021; 50(3): 550-551

DOI: http://doi.org/10.4038/sljch.v50i3.9756

(Keywords: SARS-CoV-2, vertical transmission)

\section{Introduction}

Coronavirus Disease 2019 (COVID-19) is a highly infectious disease caused by the Severe Acute Respiratory Syndrome-Coronavirus-2 (SARS-CoV$2)$. Though primarily spread through respiratory droplets, researchers have been able to isolate the viral ribonucleic acid in blood, faeces, placental tissue and amniotic fluid raising the possibility of other forms of viral transmission ${ }^{1}$. Data on potential vertical transmission do exist, except it is not specifically proven whether these cases are due to transplacental exposure or due to postnatal contact with COVID-19-positive parents or healthcare workers $^{2}$. We report a case where a newborn displayed probable evidence of vertical transmission of the SARS-CoV-2.

\section{Case report}

A baby girl was delivered by emergency caesarean section to a 36 year old G3P1 mother at 38 weeks of gestation. Mother is from Mulleriyawa, which is situated in the Colombo district and identified as a "high risk" area for SARS-CoV-2 infection by the Epidemiology Unit, Sri Lanka.

Mother was well previously. She is an officer working at the Attorney General's office in Kolonnawa. Her husband is a businessman whose job involves travelling across districts. Her antenatal period was uncomplicated apart from anaemia of pregnancy. She presented with reduced fetal movements along with a one day history of fever, cough and sore throat. On admission, she was febrile with a pulse rate of 108 beats per minute and blood pressure of $118 / 69 \mathrm{mmHg}$. Nasopharyngeal Reverse Transcriptase-Polymerase Chain Reaction (RT-

${ }^{1}$ Registrar in $\quad$ Paediatrics, ${ }^{2}$ Consultant
Neonatologist, Sri Jayewardenepura General
Hospital, Sri Lanka
${ }^{*}$ Correspondence: isharakumarasiri29@gmail.com

(iD) https://orcid.org/0000-0002-8492-5734

(Received on 03 June 2021: Accepted after revision on 16 July 2021)

The authors declare that there are no conflicts of interest

Personal funding was used for the project.

Open Access Article published under the Creative

Commons Attribution CC-BY CC (P) License

PCR) done on admission was positive for SARSCoV-2. Her laboratory investigations revealed a haemoglobin level of $10.6 \mathrm{~g} / \mathrm{dl}$ and a platelet count of $145,000 / \mathrm{cu} \mathrm{mm}$. The cardiotocogram (CTG) on admission showed no evidence of fetal distress. She was managed symptomatically. The day following admission; the CTG demonstrated prolonged decelerations and an emergency lower segment caesarean section was performed.

Non asphyxiated baby was born weighing 2,500g. Apgar score and neonatal examination were normal. RT-PCR performed on baby's oropharyngeal sample, obtained prior to handing over the baby to the mother, was positive with a Cycle threshold $(\mathrm{Ct})$ value of 24.93. The same sample was re-tested, and positivity was confirmed. A repeat oropharyngeal sample obtained at 24 hours of age demonstrated a Ct value of 21.13 on RT-PCR.

Chest x-ray, complete blood count, C-reactive protein, renal and liver function tests performed at two days of age were normal. Baby was asymptomatic throughout and was discharged at 10 days of age when the mother was considered noninfective. Hence, probable vertical transmission of the SARS-CoV-2 from an infected mother to her fetus was confirmed.

\section{Discussion}

The diagnosis of vertical transmission of SARS CoV-2 poses a dilemma due to the scarcity of data. Here we report a case of possible vertical transmission of COVID-19 infection supported by two positive neonatal oropharyngeal RT-PCR tests done immediately after delivery and at 24 hours of age with confirmed maternal infection during the pregnancy ${ }^{1}$.

The vertical transmission of corona viruses is reported to be rare ${ }^{4}$. Nevertheless, the likelihood of placental transmission can be supported by presence of angiotensin-converting enzyme 2 and transmembrane serine protease 2 in placental epithelium, which are paramount in cellular infiltration of the SARS $\mathrm{CoV}-2^{3}$. A systematic review by Kotlyar AM, et $a l^{4}$ revealed that there is a $3.2 \%$ risk of transmitting the virus by infected mothers in the third trimester as confirmed by nasopharyngeal RT-PCR. But the effect of the virus in the fetal tissue remains unsolved due to the lack of scientific data. 
As the RT-PCR only confirms the presence of viral RNA material, it is necessary to repeat the test to demonstrate the persistence of the viral material on the neonate ${ }^{1}$. This eliminates the possibility of cross contamination with maternal body fluids and amniotic fluids giving false positive results. In our patient, a positive oropharyngeal RT-PCR immediately after delivery and the persistence of the positive result at 24 hours of age strongly supports vertical transmission of the virus.

Neonatal IgG levels reflect maternal immune response while the IgM levels can represent the fetal response to an infection ${ }^{4}$. The timing of the infection, whether in-utero, intrapartum or postpartum can be differentiated by determining at which age the antibodies are present ${ }^{1}$. Thus, confirmation of vertical transmission of SARSCOV-2 by serology requires more than one positive sample. The positivity of a sample of placental tissue or amniotic fluid is considered diagnostic of infection in the mother ${ }^{1}$. However, this is not the case for the neonate due to the chance of contamination with maternal body fluids. We were unable perform RT-PCR on amniotic fluid and the placenta as such sample taking was not included in the national guidelines. The best demonstration of the vertical transmission was reported by Vivanti $\mathrm{AJ}$, et $a l^{5}$ where the viral materials were exhibited, in placenta, amniotic fluids and neonatal blood samples.

In conclusion, we imply possible vertical transmission of SARS-CoV-2 virus with positive evidence of transmission in the neonate. However, lack of data poses a challenge in predicting later outcomes of the neonates who have acquired the virus in-utero or during delivery.

\section{References}

1. World Health Organization. Definition and categorization of the timing of mother-tochild transmission of SARS-CoV-2: scientific brief, 8 February 2021. World Health Organization; 2021.
2. Bandyopadhyay T, Sharma A, Kumari P, Maria A, Choudhary R. Possible early vertical transmission of COVID-19 from an infected pregnant female to her neonate: a case report. Journal of Tropical Pediatrics 2021; 67(1):fmaa094. https://doi.org/10.1093/tropej/fmaa094 PMid: 33221859 PMCid: PMC7717437

3. Morotti D, Cadamuro M, Rigoli E, Sonzogni A, Gianatti A, Parolin C, et al. Molecular pathology analysis of SARSCoV-2 in syncytiotrophoblast and Hofbauer cells in placenta from a pregnant woman and fetus with COVID-19. Pathogens 2021; 10(4): 479. https://doi.org/10.3390/pathogens 1004047 9

PMid: 33920814 PMCid: PMC8071113

4. Kotlyar AM, Grechukhina O, Chen A, Popkhadze S, Grimshaw A, Tal O, et al. Vertical transmission of coronavirus disease 2019: a systematic review and meta-analysis. American Journal of Obstetrics and Gynecology 2021; 224(1): 35-53. e3.

https://doi.org/10.1016/j.ajog.2020.07.049

PMid: 32739398 PMCid: PMC7392880

5. Vivanti AJ, Vauloup-Fellous C, Prevot S, Zupan V, Suffee C, Do Cao J, et al. Transplacental transmission of SARSCoV-2 infection. Nature Communications 2020; 11(1): 1-7. https://doi.org/10.1038/s41467-020174366

PMid: 32665677 PMCid: PMC7360599 